\title{
Pragmatism in the Third Reich
}

Heidegger and the Baumgarten Case

\section{Hans-Joachim Dahms}

\section{(2) OpenEdition \\ 1 Journals}

Electronic version

URL: http://journals.openedition.org/ejpap/1524

DOI: 10.4000/ejpap. 1524

ISSN: 2036-4091

\section{Publisher}

Associazione Pragma

\section{Electronic reference}

Hans-Joachim Dahms, «Pragmatism in the Third Reich », European Journal of Pragmatism and American Philosophy [Online], XI-1 | 2019, Online since 19 July 2019, connection on 21 July 2019. URL: http://journals.openedition.org/ejpap/1524; DOI : 10.4000/ejpap.1524

This text was automatically generated on 21 July 2019.

\section{(c) $($ ) $\odot$ (8)}

Author retains copyright and grants the European Journal of Pragmatism and American Philosophy right of first publication with the work simultaneously licensed under a Creative Commons AttributionNonCommercial-NoDerivatives 4.0 International License. 


\title{
Pragmatism in the Third Reich
}

\author{
Heidegger and the Baumgarten Case
}

\author{
Hans-Joachim Dahms
}

\section{AUTHOR'S NOTE}

I published some years ago an article covering briefly the current subject: Dahms (1987/1998: 299-303). In the meantime new literature appeared on the theme, especially Vogt 2002 and Hausmann 2003. Whereas Hausmann tackled the task from the viewpoint of American Studies in Germany, though adding a number of new sources, Vogts writes as a historian of philosophy without considering any archival files concerning the Baumgarten case. I will not only comment on these works, but also add some new sources from the Göttingen university archive and its library. I thank Prof. Robert P. Ericksen (Gig Harbour, Wa., USA) for valuable help in improving my English draft.

\section{Introduction}

1 A very peculiar picture emerges when one looks at the reception of American pragmatism in Germany and takes not only the third Reich into account, but the entire 60 year timespan from 1900 to 1960, that is: the period of the Wilhelminian Empire, the Weimar Republic, the Third Reich and the Federal Republic till around 1960. Each of these periods covers 15 years more or less, and so may be compared. If one would only take into account the political and historical situation, the Großwetterlage so to speak, one would probably assume that the intensity of German dealings with pragmatism would show the following order:

1) Federal Republic,

2) Weimar Republic,

3) Wilhelminian Empire,

4) Third Reich. 
2 The strange thing now is that the real order seems the reverse. I will not try to create the illusion that one could measure exactly a complex entity such as intensity of reception in general and cross-border in particular. That is not possible, because number and kind of international contacts between scientists, reviews and translations of foreign books, the amount of secondary literature and dealings in lectures and seminars are each difficult to grasp, let alone to be combined into a weighted summary criterion. Also the (positive or negative) evaluations contained in or implied by those activities and their results need to be considered.

3 Nevertheless I will try to give some hints for the justification of my thesis. These may serve at the same time as a short overview of the reception of pragmatism in Germany, before I then concentrate on my main theme in this article: pragmatism in the Third Reich.

4 The relatively widespread reception of pragmatism during the Wilhelminian empire has surely its main cause in the fact that William James, as the best-known pragmatist, published in 1907 a popular synthesis of his philosophy under the title Pragmatism. A New Name for some Old Ways of Thinking, ${ }^{1}$ which was translated a year later by Wilhelm Jerusalem into German. ${ }^{2}$ In this small book James not only propagated and defended the pragmatic maxim of the founding father of pragmatism, Charles Sanders Peirce, but also tried to apply the maxim to the problem of truth. According to his theory the truth of a belief consists in one formulation in its verification, in another one in the usefulness for the bearer of that belief.

5 At the Third International Congress of Philosophy 1908 in Heidelberg, Pragmatism made a first big appearance on the European continent. The theme "pragmatist theory of truth" was by far the most widely discussed at the whole congress. Only very few German philosophers present in Heidelberg missed the opportunity to give their opinion on James's pragmatism. Many published a critical review afterwards (including Moritz Schlick, ${ }^{3}$ the founder of the Vienna Circle). But that reception was more or less superficial: most of James's critics leaned only on the chapter on truth and not at all on the introduction and the last one, where James propagated his theory as a "happy harmonizer" between the fact-orientated "toughminded" and the "tenderminded," who preferred a religious world-view. The toughminded were given "truth" as verification in James's book, the tenderminded truth as usefulness, as a guide to life. As far as I know, no full-fledged monograph on pragmatism came forward in Germany at the time.

During the following period of the Weimar Republic, only a few articles on pragmatism were published in Austria by Wilhelm Jerusalem, the translator of James's Pragmatism book. ${ }^{4}$ Max Scheler's book, Die Wissensformen und die Gesellschaft, came a little later in Germany. There Scheler conceded a role for a pragmatistic interpretation of some of the sciences, namely the natural sciences, but refused to extend such an interpretation to the humanities and theology. ${ }^{5}$

7 During the Third Reich, well-informed monographs on pragmatism appeared for the first time in German in 1936 and 1938, namely the two volumes of Die geistigen Grundlagen des amerikanischen Gemeinwesens (the spiritual foundations of the American community) by Eduard Baumgarten. ${ }^{6}$ Part one dealt with Benjamin Franklin, a pragmatist "avant la lettre" in the eye of the author. Part two was called, Der Pragmatismus: R. W. Emerson, W. James, John Dewey. ${ }^{7}$ Later on a number of publications appeared which leaned on the second part, namely by Wilhelm Burkamp, ${ }^{8}$ Arnold Gehlen ${ }^{9}$ and Helmuth Schelsky. These 
publications are better informed about pragmatism than their forerunners in the two previous periods (with the possible exception of Scheler) and evaluate it throughout more positively.

8 Afterwards in the early Federal Republic of Germany (up to 1960), only a small but extremely well-informed book was published by Jürgen von Kempski on Peirce in $1952 .{ }^{10}$ In it Kempski filled the gap which was left open by Baumgarten's strange omission of Peirce.

Now for the question that I will try to answer in this article: how can one explain the fact that the most intense philosophical reception of pragmatism in Germany up to the 1960s took place in the Third Reich, where one would expect perhaps the opposite, a revival of German leadership aspirations in philosophy or a sort of philosophical autarky (perhaps masked with a German doppelgänger for pragmatism like Nietzsche)?

The answer to that question is - to put it shortly - that the blossoming of the German reception of pragmatism in the Third Reich had a prehistory during the Weimar Republic, which I will sketch in a first section. It came about by the first organized exchange of young scientists and philosophers between Germany and the USA, which led to firsthand-knowledge of pragmatism.

11 A book project based on that close experience was almost aborted during Nazi rule, and not only that, its author (namely Baumgarten) almost lost his job and all hope to pursue an academic career. That was a consequence of a negative expert opinion (Gutachten) on Baumgarten by Martin Heidegger, who was without doubt at the time the most prominent German (and at the same time National Socialist) philosopher, who seemingly dreamed in the first year of the dictatorship to play the role of a "Führer des Führers." This Heidegger-Baumgarten affair I describe in the second section.

That Baumgarten could prevail in the end, get a habilitation, publish his book and later on even got a philosophy chair in Königsberg, can only be explained by the circumstance that he built ties with the rising star in Nazi philosophy, who so to speak succeeded Heidegger as Führer of German philosophy, a certain Alfred Bauemler. Baeumler had built a career in philosophy at the university of Dresden prior to 1933. He was known as co-editor (together with Manfred Schröter) of the prestigious Handbuch der Philosophie (Handbook of Philosophy), which started in 1926 and, for our theme more importantly, also of an edition of the works of Friedrich Nietzsche from 1930 onwards. It was he who already in 1931 depicted Nietzsche as a propagandist of the authoritarian state in his book, Nietzsche als Philosoph und Politiker. ${ }^{11}$

But Baumgarten's alliance with Baeumler came at a cost. Although he had already tried to appear as a Nazi shortly after 1933, Baumgarten now needed to rewrite his book manuscript thoroughly, mainly in two directions: a "re-interpretation" of the democratic tendencies and traditions of pragmatism and an assimilation of pragmatism with Nietzsche's philosophy. Baumgarten's alliance with Baeumler I describe in the third section.

was Baumgartens pragmatism-book reviewed both in Germany and in the USA? It is remarkable that it was received on the whole better in pragmatism's homeland than in Germany. I describe and discuss this divergence in section four.

15 After his habilitation and the publication of the pragmatism-book Baumgarten had to wait a couple of years, before he was promoted surprisingly in 1941 to one of the most prestigious chairs of philosophy: the Kant-professorship in Königsberg. It seems that he 
embraced during that period national-socialist ideology more fully than in his Göttingen years. A sketch of this episode I give in section five.

16 Concluding remarks try to answer the question whether it is justified to call Baumgarten a Nazi philosopher.

\section{Baumgarten and Pragmatism (prior to 1933)}

17 In order to understand the following some facts about Eduard Baumgarten's biography and his academic career must be stated. He (26.8.1898-15.08.1982) stemmed from a liberal academic family. His father, Fritz Baumgarten, had been director of a Gymnasium and later on university professor in Freiburg. ${ }^{12}$ The famous brothers Max and Alfred Weber were his uncles, as was Otto Baumgarten, a liberal theologian, who towards the end of the 1920s became chairman of the German league of Human Rights. Baumgarten immediately after his final exams at school volunteered as a soldier in the First World War. During that time he came into contact with Heidegger who at the time served as an agent in the office of postal censorship in Freiburg. After studies of philosophy and sociology in Heidelberg and Munich (there still with Max Weber before his premature death in the spring of 1920), Baumgarten submitted his dissertation with Alfred Weber in Heidelberg under the longish title, "Inner forms of human community. Material sociological investigations for the interpretation of the present cultural movement." The thesis remained unpublished. After receiving his doctorate he - together with 12 other postgraduates - took a scholarship for the USA from an organization founded by Alfred Weber ${ }^{13}$ which shortly later became the Deutsche Akademische Austauschdienst. Baumgarten visited as a postdoctoral student (not as a visiting professor), ${ }^{14}$ first in the winter semester of 1924/25 at Columbia university in New York, and in the summer semester of 1925 at Harvard. While in New York he came in contact with Dewey and some of his pupils, an encounter which led to his plan to translate Dewey's "Experience and Nature." ${ }^{15}$ When Baumgarten asked Dewey for his opinion on the introduction Baumgarten had written for the envisaged German edition, he received the following response:

[...] you have stated the tenor of my ideas with great exactness and clearness; I have no criticisms to make, either of the general statement or of the analysis of "Experience and Nature" [...] I almost wish I could help you with some adverse comments, but as it is I can only beg you to go ahead and wish you godspeed. I feel most grateful to have you as an interpreter of my ideas in German thought. ${ }^{16}$

After his stay in New York and Harvard and several short-time engagements elsewhere, Baumgarten served as lecturer and assistant professor at the University of Wisconsin in Madison from spring 1926 onwards. His future wife, Grete (also a former guest-student from Germany, whom he met at Harvard), had attained there an assistant professorship in ancient history earlier. In Madison Baumgarten offered mostly courses on German contemporary philosophy. He also showed a lively interest in the culture and philosophy of his host country, especially for pragmatism.

Baumgarten left the USA in 1929, first on a leave of absence from the university of Madison, in order to study current trends in German philosophy. In 1931 he decided to quit his position in the USA and go permanently back to Germany. Heidegger, who was called to the prestigious philosophy chair in Freiburg in 1929 as succesor of Husserl, had offered Baumgarten a position as assistent professor. Already in the first Heidegger seminar, however, focused on Kant, it came to a clash between the two on proper 
interpretation of the categorical imperative. This meant that any hope for the assistant professorship died immediately as well.

In place of Baumgarten, the assistant position in Freiburg went to Werner Brock, a pupil of the phenomenologist philosopher Moritz Geiger in Göttingen and son in law of Herman Nohl, a follower of Wilhelm Dilthey who, after a stint in Jena, became a professor of pedagogy in Göttingen. ${ }^{17}$ None of these connections, however, protected Brock, when shortly afterwards he was dismissed as a Jew in Freiburg by the Nazis. Heidegger gave him at least a letter of recommendation for an exile in England. ${ }^{18}$

What became of Baumgarten? He was determined to pursue his career in Germany (even later on in the Third Reich) and he got very prominent backing. It was the former Prussian minister of Culture Carl Heinrich Becker, who organized a small campaign in favor of Baumgarten. Becker singled out the Göttingen pedagogy professor Herman Nohl to head this campaign, and Nohl in turn asked a number of professors to give their expert opinions on Baumgarten.

In this context the opinion of Edmund Husserl is the most noteworthy:

[...] How seriously he (Baumgarten) took his intellectual growth and his intention to influence the totality (Gesamtheit) of the German population is shown by his leaving the beautiful and secure position in Madison, and also by the passionate energy he has shown in recent years in his scientific work. The failure of his habilitation project in Freiburg - considering the circumstances - only documents his honour; it is testimony to the strength of his individuality, which does not let him deviate, neither by fashionable suggestions (let alone personal favours), from what he gained as his own insight and conscientious work. ${ }^{19}$

One might overlook here - reading only the praise of Baumgarten's character and work the term "fashionable suggestions," against which Baumgarten had struggled. Given the circumstances, this anonymous hint can be interpreted only as a criticism of Heidegger's work. Seen in this way, it shows the split in the German phenomenological movement already before 1933, that is, between its founding father Husserl and his most prominent follower, Heidegger.

There is another letter written by one of the elder statesmen in German philosophy in Baumgarten's favor, namely by Heinrich Rickert, the head of the southwestern branch of Neukantianism, a letter which survives in the Baumgarten personal file at Göttingen university. Rickert writes that he had known Baumgarten even as a child. When he met him again later on, Baumgarten made an unfavorable, immature impression, giving Rickert no inclination to discuss philosophical issues with him. He then heard from Marianne Weber, Max Weber's widow, that Baumgarten had experienced a hard fight for survival in the USA. When he came back from America, he "was changed completely." He had considerably matured and was very sympathetic now. Rickert found his information on American universities and American youth interesting, and now this more mature Baumgarten made a very good impression on him. ${ }^{20}$

Baumgarten's ties to the Göttingen academic scene as well to some of the most prominent German philosophers helped him in the end to achieve a lecturer position for American studies (Amerikakunde) at the English Seminar at Göttingen in 1933. Amerikakunde was not introduced in Göttingen by the Nazis, as Hausmann has it. ${ }^{21}$ There was a long tradition in place in Göttingen, which dated back to the time when the university had been - before the annexion of the kingdom of Hannover by Prussia in 1866 - the university of the state of Hannover (Landesuniversität). Plans to found an entire institute for American studies 
before the First World War did not materialize. But at least the subject was covered from 1921 onwards by an honorary professor, the US-American Thomas Cuming Hall, until he reached emeritus status in $1931 .^{22} \mathrm{He}$ had been also in charge of the EnglischAmerikanischer Kulturkreis (English-America Culture Circle), ${ }^{23}$ which cared for visiting student from Britain and the USA and organized public lectures given mostly by experts from outside Göttingen.

The aftermath of the economic crisis of $1929 \mathrm{ff}$. then led to the idea to pursue Amerikakunde with younger (and cheaper) lecturers instead. Baumgarten was invited to give a lecture on the 15th of November 1932 in the English-American Culture Circle of the University of Göttingen on "Benjamin Franklin and the psychology of American everyday life (Alltag)." ${ }^{4}$

Although he had published next to nothing (even his dissertation remained unpublished), he seems to have made a good showing at this event, which gave him the upper hand over a rival candidate, Dr. Plessow, in the discussions of the philosophical faculty.

Hans Hecht, the director of the English seminary, then asked the faculty to decide the lectureship case in favor of Baumgarten - in a letter which was sent on the 30th of January 1933, the exact date of the Nazi "seizure of power." The faculty had agreed on the 17th of January. ${ }^{25}$ While the decision-making about his lectureship in the faculty in Göttingen and the ministry in Berlin dragged on (possibly caused by the turnover in the administration after the Nazi "seizure of power"), Baumgarten prepared extensive programs for his lectures and seminars, as he reported to Hecht. The themes he proposed were centered on the philosophy of Peirce, James and Dewey, American psychology (James and Watson) and pedagogy (Dewey). What he then actually taught after 1933 is a bit different: Peirce is no longer mentioned, nor Watson.

The relevant document for the lectureship was sent in April 1933 to the ministry, now under the Nazi - and former Göttingen student of classical philology - Bernhard Rust. Already in May Baumgarten should have started his courses, but it seems that the time between obtaining the lectureship and the publication of the personal- and lectureprogram was too short to announce his course for the summer-semester 1933. For the winter-semester 1933/34, he announced in any case a lecture series "American man as seen in his philosophy (Emerson, James, Dewey)." That is almost identical with the main idea of his pragmatism book of 1938. Relevant for his publications were also the lectures from the winter-semester 1936/37 "Emerson" and the winter semester 1937/38, again "Emerson."26

Baumgarten's habilitation thesis is not my main subject here, pragmatism is. But it is important for the following to know at least approximately what the main trends are in it. I think that one of the members of the habilitations commission described the content remarkably well. Hans Lipps, promoted from Göttingen to a philosophical chair in Frankfurt in 1935, wrote from there:

The present monograph about Franklin is the middle piece of a book on the "worldview foundations of the American community." Two thesis are presented:

1. the entire theological-political body of ideas of the colonial commonwealth of the earlier 17 th century was captured and radically secularized to a purely political "common sense";

2. In doing this Franklin was the real inaugurator of the following American philosophy in the 19th and 20th century, he was the first American "pragmatist." 27

It seems that Lipps was also helpful to provide a publisher for the Franklin-book. ${ }^{28}$ 


\section{The Heidegger-Baumgarten Affair}

\section{Amerikanischen Gemeinwesens, Band I"29 ("Foundations of the American community,} part one: Benjamin Franklin. The Teaching Master of the American Revolution"), his career came to an abrupt end as a result of the following expert opinion on him from Martin Heidegger, which seemingly had followed Baumgarten after his move from Freiburg to Göttingen. I need to quote the letter from the 16th of December 1933 in full:

Dr. Baumgarten attended from 1929 to 1931 my lecture courses and seminars with the intention to habilitate in Freiburg in philosophy. During that time it became clear that he neither scientifically nor morally (charakterlich) was suitable. I made that clear to him in 1932 and ended personal contacts with him.

Baumgarten stems in his relationships as well as his intellectual attitude from the liberaldemocratic Heidelberg-based circle of intellectuals around Max Weber. During his stay here he was everything other than a National Socialist [...]. I am surprised to hear that he is lecturer (Privatdozent) in Göttingen, because I cannot imagine on the basis of which scientific achievements he was admitted for habilitation. After Baumgarten had failed with me, he had lively contacts with the Jew Fränkel, who worked earlier in Göttingen and now was dismissed here. I assume that Baumgarten has accommodated himself in Göttingen in this way, which may also explain his actual connections there. Baumgarten is very clever rhetorically. In philosophy I regard him as a deceiver without a thorough and sound knowledge. This judgment is based on my acquaintance two years ago. Whether a real change of his political outlook has prepared itself in the meantime, I don't know. Because of his stay in America, during which he was americanized considerably in outlook and ways of thinking, he has doubtless achieved good knowledge of the country and its people. But I have considerable reasons to doubt his political instinctive reliability and capability of judgment. Basically there is always the possibilty that Baumgarten changes thoroughly and strengthens. But it needs a proper (trial period?). I find at the moment his entrance into the SA as equally impossible as into the Dozentenschaft (the association of academic lecturers). ${ }^{30}$

There are other copies of slightly different versions of Heidegger's opinion. The original did not survive. The files of the Göttingen chapter of the Dozentenschaft, to which it was seemingly addressed, were all burned by its last Führer, the classical philologist Hans Drexler, shortly before the end of the Second World War. ${ }^{31}$ After 1945 Heidegger tried to downplay the importance of his expert opinion in his denazification process. He wrote to a member of the denazification committee that he had been asked from Göttingen to give his judgment on Baumgarten's scientific abilities and his National Socialist reliability. Regarding this aspect he had pointed to Baumgarten's liberal descent (but he omits his reference to "the Jew Fränkel"). Heidegger also avoids identifying who "in Göttingen" asked him to give his opinion.

Very telling in Heidegger's Gutachten is the antisemitism, which was brought up first as a theme in Toni Cassirer's book. ${ }^{32}$ It was then discussed anew, when a letter from the late 1920s (that is: before the Nazi "seizure of power") was published, and later on resurfaced again after the publication of Heidegger's black notebooks. ${ }^{33}$ In my view Heidegger was not an antisemite on principle, but used it here and there as a means to discredit enemies. Think of the "Jews" in his environment: his forerunner Edmund Husserl, his pupils Karl Löwith and Herbert Marcuse or his relation with Hannah Arendt. In the context of the Heidegger-Baumgarten affair, it is also noteworthy that he preferred the "Jew" Werner Brock to the "aryan" Eduard Baumgarten. Furthermore, Heidegger's suspicion that 
Baumgarten had achieved his position in Göttingen through a connection with "the Jew Fränkel" is wrong, (as I showed above).

It seems that after the winter 1933/34 Heidegger's opinion slept in the files of the Dozentenschaft, until Baumgarten again "wanted something," now indeed to undergo the habilitation process.

Martin Heidegger in November/December 1933 surely was the most prominent German philosopher, because of his philosophical stature as the author of Sein und Zeit and the Davos dispute with Ernst Cassirer, but also because of his extraordinary engagement for National Socialism. It became public for the first time in his famous speech as Rector of Freiburg University, "Die Selbstbehauptung der deutschen Universität" (The Selfaffirmation of the German University), with its famous propagation of the trias of Arbeits-, Wehr- and Wissensdienst (labor, military and knowledge service) and many other speeches and activities. ${ }^{34}$ It remains to be explained how Baumgarten, depicted as liberal, associated with Jews and, furthermore, mostly unknown in academic circles won that struggle in the end.

\section{The Rescue of Baumgarten's Habilitation and of his Pragmatism Book and its Ideological Costs.}

At first Baumgarten's case seemed hopeless. The Dozentenschaft not only denied the habilitation, but also demanded a time-limit for his lectureship. They argued that Baumgarten was not suited to present American studies in the National Socialist state, given his time in America, because, "There is the danger that many foreigners are not acquainted with National Socialism in the sense it needs to be under all circumstances." 35 The preferred limitation for Baumgarten's lectureship was a half year.

So how could Baumgarten's career and his habilitation on the foundations of American society, the second part of which was his book on pragmatism, survive and prevail?

Baumgarten was able through "connections" in the office of the Dozentenschaft to look into Heidegger's opinion. He then got an appointment with the leader of the Göttingen chapter of that organization, the medicine professor Werner Blume, and was allowed to describe the whole conflict with Heidegger from his perspective, backing it up with a lengthy documentation. ${ }^{36}$ As a first step toward regaining respectability for Baumgarten, the new professor of English studies, Hans-Oskar Wilde, ${ }^{37}$ intervened. At the age of only 28, he had replaced the "Jew" Hans Hecht. ${ }^{38}$ Now, in his capacity as the new dean of the Philosophical faculty at Göttingen, he asked the leader of the Dozentenschaft for a rejection of Heidegger's expert opinion. He indeed got it. The leader of the Dozentenschaft wrote:

There have been at different times expert opinions on Dr. E. Baumgarten issued by the Dozentenschaft. All these opinions I would now like to supplement. Our former opinions were based on information negative for Baumgarten coming from Freiburg. We today have come to the conclusion that this information was not valid and that false facts have been reported. Under these circumstances, and especially since I have come to know Dr. E. Baumgarten better, I declare now that the Dozentenschaft will always speak up in favor of Dr. Baumgarten..$^{39}$

From then onwards everything went as quick as lightning. The required colloquium lecture to be delivered by Baumgarten took place less than a week later. It was on Kant's categorial imperative, exactly the theme over which Baumgarten and Heidegger's ways had parted before 1933. In order to take the final step toward the status of Privatdozent, 
Baumgarten had to undergo a "Gemeinschaftslager" (community camp) - the name given to paramilitary drill and ideological indoctrination at Rittmarhausen near Göttingen. ${ }^{40}$

It seems that Baumgarten had in the meantime found a powerful ally, namely Alfred Baeumler (19th of November 1887-19th of March 1968). When exactly that happened I don't know. Baumgarten wrote about this encounter on other occasions, but the original correspondence between the two men from the 1930s is not accessible. ${ }^{41}$

Baumgarten said at the end of 1938 in a letter about his relationship to Baeumler:

Herr Baeumler in 1935 took notice of some of my works, got interested in them, invited me to a scientific discussion and, as a result, let me publish some longer articles in his journal; he gave me good advice in 1936 about the call to the University of Berlin (a.o. chair for national science (Nationenwissenschaft)) and invited me to a meeting [...] with Reichsleiter Rosenberg [...]. ${ }^{42}$

Who was Baeumler? As I indicated in the introduction, he built his academic career before 1933 with the edition of the Handbook of Philosophy ${ }^{43}$ and an edition of Nietzsche's works. ${ }^{44}$ But he also leaned politically early on towards fascism, especially in his small book, "Nietzsche as philosopher and politician," of $1931 .{ }^{45}$ Its content does not need to be treated here at length. However, he reviewed there all of Nietzsche's antidemocratic and antisocialist polemics. ${ }^{46}$ In his epilogue, Baeumler reminded readers of Nietzsche's recommendation for a close coalition with Russia (at Nietzsche's time the Czarist empire, at Baeumler's the Soviet state) on the one hand and his admonition against an Americanstyle future on the other. The last paragraph reads:

Germany can exist on the world stage only under the form of greatness. It has the choice only to be the anti-Roman power of Europe or not to exist at all. If it integrates into the civilisation of the West, it submits to Rome; if it forgets its Germanic descent, it submits to the east. The creator of a Europe which is more than a Roman colony, can only be the nordic Germany, the Germany of Hölderlin und Nietzsche. Germany does not belong alongside Bismarck, it belongs in the age of the Great War. The German state of the future will not be a continuation of Bismarck's creation, it will be created from the spirit of Nietzsche and the spirit of the Great War. ${ }^{47}$

Shortly after the publication of this book, Baeumler also went public politically when he joined the National Socialist "Kampfbund für deutsche Kultur," founded by the Nazi party's ideologue, Alfred Rosenberg, when he signed on the 27th of July 1932 a call on university professors to vote for Hitler. ${ }^{48}$ These several activities earned Baeumler a newly founded chair for philosophy and political pedagogy in early 1933 in Berlin. The university and the philosophical faculty were not even asked to give an opinion on that move. Already on the occasion of the bookburnings in May 1933 Baeumler gave a speech to the Nazi students. ${ }^{49}$

Now three years later, when the Baumgarten case entered its decisive stage, Baeumler had been promoted in Rosenberg's administrative body, comissioner of the Führer for the supervision of the whole ideological training and education of the NSDAP ("Beauftragter des Führers für die Überwachung der gesamten geistigen Schulung und Erziehung der NSDAP") to the directorate of the Amt Wissenschaft (science office). This not only allowed him to mingle within the Nazi-party, but also gave him significant influence within science and education as a whole. ${ }^{50}$

Heidegger had held American pragmatism in low esteem, having said for instance in Freiburg to Baumgarten that Dewey was not worthwhile to study because he lacked a philosophical niveau of his own..$^{51}$ That opinion on pragmatism was endemic among 
German philosophers. ${ }^{52}$ So why did Baumgarten (and Baeumler) not share this widespread suspicion and resentment?

We can look at several choices Baumgarten made in preparation, before his books were ready for publication. The overall idea of his book series included,

1) his decision to start with Benjamin Franklin,

2) his decision to shape the second volume, the one on pragmatism, around the inclusion of Emerson, and the omission of Peirce,

3) and his "reinterpretation" of pragmatism's relationship to democracy.

Ad 1) Baumgarten's book series was meant to show that pragmatism was the systematized version of a way of thinking that was present already in early stages of the American revolution and embraced intuitively by some of its leading figures like Franklin. The thesis is not that philosophers like James and Dewey somehow followed consciously Franklin's steps or even cared about his works. According to Baumgarten, they rationalized or - to use the phrase of Ernst Rothacker - highly stylized the American spirit embodied by people like Franklin. This overall idea becomes especially transparent in the last chapter of the Franklin book.

More interesting than Baumgarten's general idea in the Franklin book seems to me his critique of certain ideas presented by his uncle Max Weber about the origins of capitalism, especially in the USA. Weber in his book, "The Protestant Ethic and the Spirit of Capitalism," had depicted Franklin as an important example of that kind of Protestant asceticism which made it possible for capitalism in the USA to flourish. Citing exact biographical information about Franklin, Baumgarten showed good reason to doubt Weber's portrayal.

50 Ad 2) Moving beyond the Franklin book, it seems quite odd from today's perspective that Baumgarten included a chapter in his pragmatism book on Ralph Waldo Emerson - while not saying anything about the founding father of pragmatism, Charles Sanders Peirce. Why is that?

51 Baumgarten seems to have convinced himself, and Baeumler, that pragmatism - and especially its alleged forerunner Emerson - had a systematic and personal relationship to Nietzsche, the philosopher whom not only Baeumler, but also his master Rosenberg, took as the decisive ideological forerunner of National Socialism. Emerson is presented as someone who enormously influenced Nietzsche. Some passages about Emerson's position vis-a-vis democracy at first glance stand in strange contrast to Baumgarten's reinterpretation of the term "democracy" in his introduction (see below):

"It is... (important, Dahms) to establish this firm taking root (Verwurzelung) by Emerson in the political realm of American democracy. Emerson was not so much prophet of a future time or of an Übermensch (like Nietzsche, Dahms), but friend of his nearest neighbors, priest of an already existing parish community and its present faith [...]. Emerson was as philosopher a democrat and an American..$^{53}$

Baumgarten described later on, how he formed the hypothesis that Nietzsche must have something to do with Emerson already during his first seminar-course in Göttingen in the summer-semester 1933, at a time when almost nobody, including the personel in the Nietzsche-archive in Weimar, would believe in the existence of such a relationship..$^{54}$ But then in the Winter-Semester 1937/38, Baumgarten went to Weimar himself and indeed found convincing corroboration for his hypothesis. ${ }^{55} \mathrm{He}$ was then given the opportunity to publish a piece about Emerson and Nietzsche in Baeumler's "Internationaler Zeitschrift für Erziehung." ${ }^{156}$ The full story about similarities and ties between Emerson and 
Nietzsche was developed later on after 1945, in a long article starting the first volume of the "Zeitschrift für Amerikakunde" in 1956. ${ }^{57}$ Baumgarten published in the documentary part of that article excerpts from Nietzsche's hand from the works of Emerson and annotations Nietzsche made in his copy of Emerson's works. Baumgarten as well described in more detail than before the various influences of Emerson on Nietzsche and also the differences between them. I cannot comment on these investigations here at length. To take just one example: Baumgarten presented the thesis that Nietzsche leaned on Emerson in his construct of the Übermensch ("the constructions of the Übermensch after models taken from Emerson") ${ }^{58}$ in his Zarathustra. Thesis 4 of Baumgarten's concluding statements reads as follows:

The impact of Emerson on Nietzsche is of a sweeping and central importance for Nietzsche's work (criticism of christianity, critic of "history," critic of the present man, outline of the idea of an Übermensch). It was at the same time for Nietzsche's life a comprehensive support.

To sum up: Baumgarten seemingly was successful in persuading Baeumler of philosophical ties between a would-be forefather of pragmatism and the man he took as the main ideological source of National Socialism: Nietzsche.

It seems that Baumgarten's articles establishing the Emerson-Nietzsche tie made no big impression on the German philosophical scene neither in the late 1930s nor afterwards in the late 1950s. The first statement of these ideas came as a hypothesis only in his pragmatism-book from 1938 and as a statement without sufficient backing of evidence in the article in Baeumler's journal shortly before the war was started by Hitler and his army. When Baumgarten's full documentation and commentary was published in 1956, Nietzsche, who was admired during the Third Reich by many inside and outside philosophy (like Baeumler), had fallen into disrespect precisely for the same reason: his role as an ideological forerunner of National Socialism.

A renewed interest in pragmatism in Germany in the 1960s neglected (or perhaps intentionally avoided) both Emerson and Baumgarten's investigations and instead leaned mostly on the real founding father of pragmatism, Charles S. Peirce. In Jürgen Habermas's Erkenntnis und Interesse as well as in Otto Apel's Transformation der Philosophie, the most important books introducing this pragmatist turn, you will not find a single mention of either Emerson or Baumgarten. ${ }^{59}$ It therefore comes as a big surprise that in recent years the Emerson-Nietzsche connection receives much attention in the USA. It is impossible here to draw a full picture of that development. However, it seems at least ironic that what was originally invented by Baumgarten as a bridge to make pragmatism welcome in dictatorial Germany now seems to serve as a way to make Nietzsche more acceptable to the USA.

It would be easier to swallow the chapter on Emerson in Baumgarten's genealogy of pragmatism, if he had not constantly omitted the real founding father of pragmatism, Charles Sanders Peirce. When one observes Peirce's description of the historical foundations of pragmatism, a very different picture emerges. It has nothing to do with the non-philosophical American community spirit, but very much with non-American philosophical forerunners. I have in mind the Scottish school of common-sense philosophy and especially Alexander Bain, its last representative. The Scottish school shared a rejection of all foundationalist philosophy, especially Descartes idea of a methodical doubt, i.e. doubting everything, until one arrives in the last resort at the doubting self, which cannot be doubted, and from that undeniable starting point begins 
to rebuild all knowledge. For the Scottish school that Cartesian idea was implausible and impossible: one can only doubt from time to time and here and there, when occasion arises, but not "methodically," because one needs belief as a guide to action. This idea was underlined by Alexander Bain, one of the last representatives of the Scottish school and the grandfather of pragmatism - in Peirce's judgment -, when he declared that all belief was a disposition to act. Whether Bain's view is defensible, I must leave out here. It gets difficult when it comes to scientific beliefs and theories, especially those concerning events remote in space and/or time. What could possibly be the corresponding actiondispositions? Peirce's pragmatism was in its content (although not in its name) first outlined in his 1878 article "How to Make our Ideas Clear." It proclaims for the first time the pragmatic maxim:

Consider what effects, that might conceivably have practical bearings, we conceive the object of our conception to have. Then, our conception of these effects is the whole of our conception of the object. ${ }^{60}$

Easier than this pronouncement is $\$ 398$ to understand:

The essence of belief is the establishment of a habit; and different beliefs are distinguished by the different modes of action to which they give rise. If beliefs do not differ in this respect, if they appease the same doubt by producing the same rule of action, then no mere differences in the manner of consciousness of them can make them different beliefs, any more than playing a tune in different keys is playing different tunes. ${ }^{61}$

Without that maxim the whole pragmatist movement is unthinkable. James relied on it as well as Dewey and every other pragmatist in the proper sense of the word.

Baumgarten at least had heard of Peirce (as the title of his planned lectures indicate). But the edition of Peirce's "Collected Papers" started only in 1931, and the volume containing pragmatism and pragmaticism was published in 1934. It went almost completely unnoticed in the Third Reich. ${ }^{62}$

Peirce's importance as the greatest American philosopher was only detected - in Germany at least - by a younger generation comprising Jürgen Habermas and Hans-Otto Apel, and even this novel declaration was met with much scepticism in the German philosophical public.

Ad 3) The second move for making pragmatism acceptable for National Socialist ears consisted in a thorough reinterpretation of American democracy, intended to make it acceptable for the ideological needs of the Nazi regime and its ideological spokesmen. Baumgarten wrote that he had to add relevant remarks and footnotes "quasi as a repetition course to the course of the text" in order to achieve this.

63 Although I have not seen the original manuscript, which is still kept in private hands, and so cannot compare it with the published version, I cite a telling example from the introduction:

Before we can turn to three philosophers of American "democracy" [...] Emerson, James, Dewey, some disturbing misunderstandings, which could enter, should be removed [...] Is not Amerian democracy, like all democracy, and it in the first place, a phenomenon of decay? Is it not the hothouse for "liberalism" and "individualism"? [...] Nothing stands in the way of a mutual understanding between Germans and the Anglo Saxons as much as these concepts, by which something different is denoted here and there. The name of democracy lives on as a concept for a political system, which was introduced at the end of a lost war in a situation of deepest national exhaustion and humiliation from outside. This hateful meaning (odium) is attached to "democracy" here. The concept of democracy in England and 
America is associated with the most glorious national memories. It is there a

concept of ascendance, of power, of enthusiasm. ${ }^{63}$ nod in the direction to National Socialism. The phrase "support through referendum" makes this clear. In November 1933 Hitler introduced a plebiscite about the exit from the League of Nations. A big demonstration of the German academic and intellectual scene gave applause to this event at a meeting in Leipzig, among them in first line also Martin Heidegger. Not less than 961 intellectuals signed the accompanying document, among them 25 academic philosophers. ${ }^{69}$ Baumgarten was not among them. Perhaps this was simply due to the fact that he belonged not yet fully to academia, because he was still working on his habilitation. Perhaps the cited paragraph is an attempt to compensate for that missed opportunity. In any case: it could hardly have escaped Baumgarten's attention that already in May 1933 all political parties had been forbidden and so democracy was overthrown; the different referenda that Hitler organized, served only the acclamation of his regime.

Between the cited article of 1934 and the publication of his book on pragmatism, Baumgarten was given by Baeumler the opportunity to clarify his position towards democracy more inclusively. He started to publish a series of articles on John Dewey in 
the Internationale Zeitschrift für Erziehung (International education review) founded in 1931 and edited by Alfred Baeumler and Paul Monroe from New York's teachers college. In the first of this series Baumgarten varied his thesis about the different meanings of "democracy" in Germany and the USA as follows:

The word "democracy" has for us a dark aura. All the lighter, I hope, it became evident, that Dewey subsumes under that concept attitudes and convictions, to which we today stand much closer to than at a time, where we did it according to name only. For a while - as a consequence of unheard-of effort and an overstrain of all forces of the nation - exactly the opposite of a democratic faith gained place among us: namely, lack of hope for the future and passivity, as a merely negative response to a bad and community-less peace, which Europe concluded. ${ }^{70}$

Baumgarten continues with a reinterpretation of Dewey's well known statement against godlike leaders: "democracy is not concerned with freaks, or geniuses, or heroes, or divine leaders." Against a "misunderstanding" that Dewey propagated a bad, leaderless and even leader-inimical (führerfeindiche) democracy, "from which we happily escaped," Baumgarten stresses the eminent role that leadership played from the very beginning in British and US-American democracy. According to this reinterpretation, Dewey only rejected "community-foreign (gemeinschaftsfremde), irresponsable leadership, which wanted blind subjects, in contrast to a leadership which "to the last house of the nation" searches its "co-workers, wakens them and makes them step in."

\section{Contemporary Judgments on Baumgarten's P ragmatism Book}

71 What about the reception of Baumgarten's work during the Third Reich in Germany and US-America? Hausmann cites only a very negative review about the Franklin book and adds that author and publisher were not able to enter into the Anglo-American sphere. ${ }^{72}$ That picture is at least one-sided and needs a correction.

\subsection{In Germany}

Baumgarten's books and articles were published in years not very suited to a favorable reception, namely in the last years leading up to the second World War. Hausmann cites from a review by Friedrich Schönemann, an engaged National Socialist expert on English literature and American studies and as such a competitor of Baumgarten, published in the Völkischer Beobachter (the daily of the Nazi party) on the 15. of August 1936:

One can only wonder, why it is possible, that such a book is presented to us as a serious piece of literature (Schriftum). One needs to have the strongest reservations against the consequences of such a spiritually confused as well as stylistically unGerman work on the foreign public. Because our German-ness must rest on a solidity born from a plain clarity and veracity, so our Schriftum can only have effect abroad and promote our cause, if it expresses such German-ness. ${ }^{73}$

It needed some effort on Baumgarten's part to convince the publisher of the Franklin book to edit also his pragmatism book. This one received a quite favorable review from Helmut Schelsky in 1940 (written, as he adds, from the front), who, after 1945 became one of the leading German sociologists. He welcomes Baumgarten's book in general and its quasi-sociological approach, saying that 
Baumgarten sees pragmatism politically as one of the "foundations of the American community," really as the philosophically interpreted and systematized spirit of Franklin and Lincoln. ${ }^{74}$

(1)

The question mark he adds is:

[...] the days [...] of the frontier are over. Are they in America not only national memories? In which degree does the present America stick to the spirit of an Emerson, even of a James or Dewey?

After raising some doubts about the inclusion of Emerson in the genealogy of pragmatism he nevertheless ends with a quite positive judgment:

It (i.e.: Baumgarten's book) brings a chapter from the history of philosophy, but one that today is of the utmost systematical interest, namely a theory of man which is in close connection with the newest insights of the disciplines studying man. Herein lies the importance of this book, in contrast to the fullness of works in the history of philosophy in which philosophy seems to drown today. So, we like to end this review with the wish, that the author starting from the historical description will arrive at a systematical [...] philosophy of man, at a treatment of the questions of consciousness, of drives, etc., which can be regarded as valid for the present time. ${ }^{75}$

\subsection{In the USA}$$
\text { after the Second World War mostly for his standard work on the history of American }
$$
philosophy, ${ }^{77}$ had during the 1920 s and 1930s developed a lively interest in Italian fascism (as a consequence of a visiting scholarship to Italy in the '20s). As an early résumé of his political investigations and experiences in Italy, he had published in 1928 the book The Making of the Fascist State. ${ }^{78}$ And only shortly before Baumgarten's pragmatism book he added in 1936 another book on the theme. ${ }^{79}$

Now Vogt in his book on pragmatism and fascism took the example of Schneider as one of two American pragmatists who had themselves fascist leanings. ${ }^{80}$ When reading only Schneider's books, one is surprised by its mostly descriptive and "positivistic" approach in describing the Mussolini dictatorship. But, as Vogts makes it clear, unpublished papers show fascist inclinations. ${ }^{81}$

But Baumgarten was not only praised by Schneider: He was invited to contribute to the very first volume of the Library of Living Philosophers founded by Paul Arthur Schilpp, a series, which afterwards became a sort of counterpart to a (missing) Nobel-prize in philosophy. The volume was dedicated to John Dewey and appeared on the occasion of his 80th birthday in 1939. In his letter of invitation Schilpp expressis verbis left it open to Baumgarten to proceed from his own standpoint or "the spiritual stance of his own people" and "to deal with the theme as critically as you like." 82 
Baumgarten tried in vain to get a permit by the German authorities to contribute an article, because Schilpp had made critical remarks about National Socialism in his book, "The Quest for Religious Realism." ${ }^{83}$ This book was prompted, as Schilpp wrote in the introduction, by the course of world events in the last quarter century. On the one hand, he began to name the First World War, the Russian revolution, the Versailles peacetreaty, and then ended in the immediate present with other events which had fallen "with increasing suddenness and tempo and with the staccato sound of a machine gun!" 84 This included "the arrival of Hitler! The rearming of Germany [...] The persecution of the Jews!" On the other hand, he went on to ask what religion could say to and do about such a world. In the chapter, "Can we both be Patriotic and Christian?" indeed he came forward with a straightforward rejection of fascism and National Socialism. In the second part of that chapter, with "illustrations from abroad, from sufficiently far away," ${ }^{85}$ he summed up his investigations as follows:

[...] it is easy to perceive that no one who takes seriously the Christian position, the Sermon on the Mount, can, in the present Italian, German, or, for that matter Russian sense, be both "patriotic" and "Christian."

The reason for this assessment for the case of Germany was clear when, as a happily naturalized US-American, he underlined that in his own native country, Germany,

"Patriotism" is today being defined as unquestioned acceptance of and absolute loyalty to the Nazi regime. Anyone who dares to disagree with the acts or with the policies of the Nazi government is considered a traitor; and, if his disagreement becomes known in official quarters, he is dealt with as such. ${ }^{87}$

As he explained elsewhere, these dealings meant to be "put into concentration camps or murdered by the state." ${ }^{88}$

To sum up: Baumgarten's work was valued highly outside of Nazi Germany by experts on pragmatism, including by people who were severe critics of the Hitler dictatorship and its ideology.

\section{Baumgarten Career in the Third Reich after his Göttingen Years}

Baumgarten had joined the Nazi party, at the earliest possible moment, in May 1937, after the first rush of joiners in early 1933 and the temporary closing off new membership.

He also was invited by Baeumler together with 29 handpicked young philosophers to the castle of Buderose (near Guben) to a conference for a week from 12th to 19th of March $1939,{ }^{89}$ the only one of that type during the entire Nazi dictatorship. This gathering was meant to further the indoctrination with Nazi ideology and screen the participants for possible later careers. It came under the very general title "Weltanschaung und Philosophie" (wordview and philosophy). Nietzsche belonged there to the themes discussed after Baeumler's lecture on Kant on the 14th of March (with Baeumler himself, Schlechta, Baumgarten and Springmeyer as discussants). ${ }^{90}$ Pragmatism had a place at most indirectly, in or after Alfred Zastrau's talk on "Das Wort Wahrheit" ("the word truth") the following day. Baumgarten, who intervened after all the other talks in the discussion, remained silent this time. Rosenberg himself invited the participants to a comrades' evening on the 16th and gave a talk on "Sense and task of the science conference." 
Baumgarten seems to have had a good showing in Buderose in the eyes of the relevant authorities. He was called in 1941 to a philosopy chair in Königsberg, in a way as a distant successor to Kant. He replaced directly Arnold Gehlen, who went to Vienna a year earlier, and who had shown in his main work from that time, Der Mensch, pragmatist tendencies and obvious knowledge of Baumgarten's work. ${ }^{91}$ In Königsberg Baumgarten developed a program for a biological pragmatism based on evolution theory. He named some people who could possibly work on that program in cooperation, but he was only partially successful in his efforts. He at least achieved a move in the opposite direction as Gehlen's voyage, that is, from Vienna to Königsberg. I have in mind Konrad Lorenz, later the very famous founder of animal ethology and a trained biologist, who received a psychology chair in Königsberg. ${ }^{92}$ They had met earlier in Göttingen, when the (also later on) famous biologist and animal physiologist Erich von Holst introduced Baumgarten to Lorenz. But the good cooperation between Baumgarten and Lorenz lasted only for a short while, before Königsberg was threatened by Soviet troops. Baumgarten gave a radio talk shortly before he and Lorenz escaped. It was a matter of fierce controversy after the end of World War II, whether this talk was meant as a hold out appeal against the "bolshevist danger" or not.

very last days of the war, Baumgarten turned up in Göttingen again. There he earned some fame as the leading spokesman of a small crew who drove out in an open military car with a white flag towards the allied troops in order to save the town from annihilation. Soon after the liberation he gave a triumphant speech to a gathering of students in which he denied German guilt in the atrocities of the National Socialist regime. That earned him a suspension from academic work for a while by the British education branch, and his denazification became ever more difficult. Especially his actions in Königsberg were held against him: did he give, for instance, a hold-out-talk via radio ln the 14th of March $1945^{93}$ or not? I do not know whether any files (in what is now) Kaliningrad or elsewhere survive. It is difficult to give an opinion on denazification matters on the basis of the Göttingen files alone.

It took a long time before Baumgarten was again admitted to a university, taught students or started publications. That came in Mannheim, where he started a new academic career. He abandoned his big theme, pragmatism, more or less completely. It is small wonder that his official position was no longer in American studies, nor was it in philosophy. Rather, he moved into sociology, with main themes during that period in organisation sociology and university reform. In the 1960s, he also turned to one of his relatives, Max Weber, who in Nazi-times had stood for a while in the way of his career. In 1964 he served as organizer of the big congress of the German sociological society in Heidelberg on the occasion of Weber's 100th birthday, and he published in that year a collection of Weber's more political works. ${ }^{94}$ So, for Baumgarten the Nazi-period, during which he wrote his major works on American society, on Franklin and on pragmatism, remained in the end a transitory one. Not a single author in the Festschrift dedicated to him on the occasion of his 70th birthday cared to write anything on pragmatism..$^{95}$

\section{Concluding Remarks}

In view of the evidence given above, one might ask, was Baumgarten a Nazi? Can it even be said that Baumgarten had a "perverted love for pragmatism," as Hans Joas assessed it? 96

European Journal of Pragmatism and American Philosophy, XI-1 | 2019 
91 First of all, one has to take into account that everyone who wanted to pursue an academic career in the Third Reich needed to find a difficult balance between his and her own beliefs and projects and the demands of the dictatorship. That applies to academics in every field, but especially in a highly ideologically-loaded subject as philosophy. ${ }^{97}$ Furthermore, unlike many others, Baumgarten had to struggle already before 1933 with the wrath of Heidegger, and later on especially with the "expert opinion" given in December 1933 and its devastating consequences. So, any judgments about what were merely opportunistic moves in order to save his career and what represented a willingness to embrace National Socialism needs to be studied very carefully, and in full knowledge of the relevant university files (which are completely neglected by Joas and Vogt).

In Königsberg, Baumgarten was much more "explicit" (as Hausmann termed it) as an ideologue of National Socialism. One only needs to read some titles of articles and booklets he published, like Der Mensch als Soldat (Man as a soldier). ${ }^{98}$ But more material has to be studied in order to form a definitive judgment on his Königsberg period, his relationship to his colleague Konrad Lorenz, his lectures and seminars, his flatly propagandistic speeches and publications, his dealings with the university and government authorities. Special emphasis needs to be laid on the radio message mentioned above, which played a big role in his Göttingen denazification process. Given the limitations of space the interpretation and evaluation of this vast and complicated material can only be attempted in another article.

\section{BIBLIOGRAPHY}

(Unpublished source) UnIVERSITÄTSARCHIV GÖTTINGEN (UAG), Protokollbuch der Philosophischen Fakultät der Georgia Augusta (1930-1949).

(Unpublished source) UNIVERSITÄTSARCHIV GÖTTINGEN (UAG), Dr. Baumgarten (signature: Phil. Pers. Baumgarten), Lehrauftrag für Amerikakunde 1933, Habilitation für Philosophie.

(Unpublished source) UNIVERSITÄTSBIBLIOTHEK GÖTtINGEN (UBG), Nachlass Herman Nohl, Akte 14: Baumgarten.

ALBERT Hans (Hrsg.), (1971), Sozialtheorie und soziale Praxis. Eduard Baumgarten zum 70. Geburtstag, Meisenheim am Glan, Hain Verlag.

APEL Karl-Otto, (1973), Transformation der Philosophie, Band 1: Sprachanalytik Semiotik, Hermeneutik, Frankfurt am Main, Suhrkamp Verlag.

BAEUMLER Alfred, (1930) “Nachwort," in Nietzsche (1930), 699-709.

BAEUMLER Alfred, (1931), Nietzsche der Philosoph und Politiker, Leipzig, Reclam Verlag.

BAEUMLER Alfred (ed.), (1926/1934), Handbuch der Philosophie (with Manfred Schröter), München, Oldenbourg Verlag. 
BAEUMLER Marianne, BRUNTRÄGER Hubert \& Hermann KURZKE, (1989), Thomas Mann und Alfred Baeumler. Eine Dokumentation, Würzburg, Königshausen \& Neumann.

BAUMGARTEN Eduard, (1919), "Nationalismus und Sozialdemokratie," in Schriften der Sozialistischen Studentengruppe der Universität Freiburg, Heft 2.

BAUMGARTEN Eduard, (1934a), "Kritische Bemerkungen zur Rektoratsrede Martin Heideggers (1933) Die Selbstbehauptung der deutschen Universisät," in Mitteilungen der Deutschen Akademischen Freischar (1934, Nr. 2).

BAUMgARTEN Eduard, (1934b), “Amerikanische Philosophie und deutscher Glaube,” in Zeitschrift für Französischen und englischen Unterricht, Bd 33 (1934), 96-112.

BAUMGARTEN Eduard, (1936), Die geistigen Grundlagen des amerikanisches Gemeinwesen, Band I: Benjamin Franklin, Frankfurt am Main, Klostermann Verlag.

BAUMGARTEN Eduard, (1936a), “John Dewey, Teil I: Die Idee der Demokratie," in Internationale Zeitschrift für Erziehung, 5 (1936) Heft 2.

BAUMGARTEN Eduard, (1938), Die geistigen Grundlagen des amerikanischen Gemeinwesens, Band II: Der Pragmatismus, Frankfurt am Main, Klostermann Verlag.

BAUMGARTEN Eduard, (1939), “Emerson-Nietzsche," Internationale Zeitschrift für Erziehung, 8, 1-16.

BAumgarten Eduard, (1942), “Der Mensch als Soldat," Blätter für deutsche Philosophie, 16.

BAUMGARTEN Eduard, (1945), Das Gedächtnis Kants und die Zukunft Europas (Rundfunkrede, Berlin 14. März).

BAUMgARTEN Eduard, (1956), "Das Vorbild Emersons im Werk und Leben Nietzsches, Teil I," Jahrbuch für Amerikastudien, Band I, 93-152

BAUMGARTEN Eduard, (1964), Max Weber - Werk und Person. Dokumente ausgewählt und kommentiert, Tübingen, J. C. B. Mohr.

BECKER Heinrich, DAHMS Hans-Joachim \& Cornelia WEGELER (eds), (1987/1998), Die Universität Göttingen unter dem Nationalsozialismus, München, Saur Verlag.

BURKAMP Wilhelm, (1912), "Biologische Bedeutung des Erkennens und Pragmatismus," Vierteljahrsschrift für wissenschaftliche Philosophie und Soziologie, 36, 477-514.

BURKAMP Wilhelm, (1938), Wirklichkeit und Sinn (2 Bände), Berlin, Junker \& Dünnhaupt Verlag. CASSIRER Toni, (1981), Mein Leben mit Ernst Cassirer, Hildesheim, Gerstenberg Verlag. DAHMS Hans-Joachim, (1987/1998), “Aufstieg und Ende der Lebensphilosophie. Das philosophische Seminar der Universität Göttingen," in Becker, Dahms \& Wegeler (eds), Die Universität Göttingen unter dem Nationalsozialismus, München, Saur Verlag, 287-317.

DAHMS Hans-Joachim, (1992), "Positivismus und Pragmatismus," in David Bell \& Wilhelm Vossenkuhl (Hrsg.), Wissenschaft und Subjektivität. Science and Subjectivity. Der Wiener Kreis und die Philosophie des 20. Jahrhunderts. The Vienna Circle and Twentieth Century Philosophy, Berlin, Akademie Verlag, 239-57.

DAHMS Hans-Joachim, (1994), Positivismusstreit. Die Auseiandersetzungen der Frankfurter Schule mit dem logischen Positivismus, dem amerikanischen Pragmatismus und dem kritischen Rationalismus, Frankfurt am Main, Suhrkamp Verlag.

DAHMS Hans-Joachim, (2003), “Philosophie,” in Hausmann (2003), 193-228. 
DAHMS Hans-Joachim, (2018), "Verpasste Chancen. Kritische Theorie und Pragmatismus," in Max Beck \& Nicholas Coomann (Hrsg.), Historische Erfahrung und begriffliche Transformation. Deutschsprachige Philosophie im Exil in den USA 1933-1945, Wien, Lit Verlag, 132-57. DEWEY John, (1925), Experience and Nature, New York, Open Court.

EBEL Wilhelm, (1962), Catalogus Professorum Gottingensium 1934-1962, Göttingen, Vandenhoeck \& Ruprecht.

FARIAS Victor, (1987), Heidegger et le nazisme. Morale et politique, Lagrasse, Éditions Verdier.

FARIAS Victor, (1989), “Heidegger und der Nationalsozialismus (mit einem Vorwort von Jürgen Habermas)," Frankfurt am Main, S. Fischer Verlag.

GEHLEN Arnold, (1940/1993), Der Mensch. Seine Natur und seine Stellung in der Welt (Hrsg. KarlSiegbert Rehberg), Frankfurt am Main (= Gesamtausgabe, Band 3), Klostermann.

HABERMAS Jürgen, (1968), Erkenntnis und Interesse, Frankfurt am Main, Suhrkamp Verlag.

HAUSMANN Frank-Rutger, (2003), Anglistik und Amerikanistik im “Dritten Reich," Frankfurt am Main, Klostermann.

HEIDEGGER Martin, (1933a/2000), Die Selbstbehauptung der deutschen Universität (27. Mai 1933), abg. in: ders. (2000), 107-17.

HEIDEGGER Martin, (1933b/2000), 289. Gutachten über Baumgarten, in: ders. (2000), 774 f.

HEIDEGGER Martin, (1946/2000), 186. Zum Gutachten über Baumgarten, in: ders. (2000), $417 \mathrm{f}$.

HEIDEGGER Martin, (2000), Reden und andere Zeugnisse eines Lebensweges (= Gesamtausgabe, I. Abteilung: Veröffentlichte Schriften 1910-1976, Band 16), Frankfurt am Main, Vittorio Klostermann.

HEIDEGGER Martin, (2014), Überlegungen XII-XV (Schwarze Hefte 1939-1941) (Hrsg. Peter Trawny), Frankfurt am Main, Vittorio Klostermann.

HINGST Kasi-Michael, (2000), “Nietzsche pragmaticus. Die Verwandtschaft von Nietzsches Denken mit dem Pragmatismus von William James," Nietzscheforschung, 7, 287-308.

JASPERS Karl, (1978), Notizen zu Heidegger (Hrsg. Hans Saner), München/Zürich, R. Piper \& Co. Verlag.

JAMES William, (1907/1975), Pragmatism. A New Name for Some Old Ways of Thinking, Cambridge, Mass, London, Cambridge University Press.

JAMES William, (1908), Der Pragmatismus. Ein neuer Name für alte Denkmethoden. Volkstümliche philosophische Vorlesungen (deutsch von Wilhelm Jerusalem), Leipzig, Klinkhardt.

JERUSALEM Wilhelm, (1907), “Vorwort des Übersetzers," in James, Der Pragmatismus. Ein neuer Name für alte Denkmethoden. Volkstümliche philosophische Vorlesungen, V- IX.

JERUSALEM Wilhelm, (1908), “Der Pragmatismus. Eine neue philosophische Methode," Deutsche Literaturzeitung, 25.01.1908, 197-206.

JERUSALEM Wilhelm, (1925), Gedanken und Denker. Neue Folge, Wien/Leipzig, Wilhelm Braumüller. JOAS Hans, (1992), Pragmatismus und Gesellschaftstheorie, Frankfurt am Main, Suhrkamp Verlag. JOAS Hans, (1992a), “Die unterschätzte Alternative. Amerika und die Grenzen der 'Kritischen Theorie'," in Id, Pragmatismus und Gesellschaftstheorie, 96-113. 
JOAS Hans, (1992b), “Amerikanischer Pragmatismus und deutsches Denken. Zur Geschichte eines Mißverständnisses," in Id., Pragmatismus und Gesellschaftstheorie, 114-45.

VON KEMPSKI Jürgen, (1952), Charles Peirce und der Pragmatismus, Stuttgart/Köln, Kohlhammer Verlag.

LEAMAN George, (1993), Heidegger im Kontext. Gesamtüberblick zum NS-Engagement der Universitätsphilosophen, Hamburg, Argument Verlag.

MÜLLER-FREIENFELS Richard, (1913), “Nietzsche und der Pragmatismus,” Archiv für Geschichte der Philosophie, Bd. 26, Berlin.

NAGL Ludwig, (1998), Pragmatismus, Frankfurt am Main/New York, Campus Verlag.

NIETZSCHE Friedrich, (1930), Der Wille zur Macht. Versuch der Umwertung aller Werte (mit einem Nachwort von Alfred Baeumler), Leipzig, Alfred Kröner Verlag.

Отт Hugo, (1988), Martin Heidegger. Unterwegs zu seiner Biographie, Frankfurt am Main, Campus Verlag.

PEIRCE Charles Sanders, (1934), Pragmatism and Pragmaticism. Scientifc Metaphysics (eds. Charles Hartshrone/ Paul Weiss) Cambridge (Mass.) (= Collected Papers vol. V and VI), Belknap Press. PEIRCE Charles Sanders, (1978/1934), "How to Make Our Ideas Clear," in Id., Pragmatism and Pragmaticism. Scientifc Metaphysics, 248-71.

RATZKE Erwin, (1987/1998), “Das Pädagogische Institut der Universität Göttingen. Ein Überblick über seine Entwicklung in den Jahren 1923-1949," in Becker, Dahms \& Wegeler (eds), Die Universität Göttingen unter dem Nationalsozialismus, München, Saur Verlag, 318-36.

SANER Hans, (1978), “Vorwort,” in Notizen zu Heidegger, München/Zürich, R. Piper, 7-21.

SCHELER Max, (1926), “Erkenntnis und Arbeit. Eine Studie über Wert und Grenzen des pragmatischen Princips in der Erkenntnis der Welt," in ders.: Die Wissensformen und die Gesellschaft , Leipzig, Der Neue Geist Verlag.

SCHELSKY Helmut, (1940), "Rezension von: Eduard Baumgarten. Der Pragmatismus," Die Tatwelt, 16, 27-9.

SCHILPP Paul Arthur, (1938), The Quest for Religious Realism. Some Paradoxes of Religion, New York/ London, Harper.

schilpp Paul Arthur (ed.), (1939), The Philosophy of John Dewey, La Salle (Illinois), Open Court. scHLICK Moritz, (1910), “Das Wesen der Wahrheit nach der modernen Logik," Vierteljahrsschrift für wissenschaftliche Philosophie und Soziologie, 34, 386-477.

scHoll Lars-Ulrich, (1998), "Um Besten der besonders in Göttingen gepflegten Anglistik. Das Seminar für Englische Philologie," in Becker, Dahms \& Wegeler (eds), Die Universität Göttingen unter dem Nationalsozialismus, München, Saur Verlag, 391-426.

SCHNEIDER Herbert W., (1928), Making the Fascist State, New York, Oxford University Press.

SCHNEIDER Herbert W., (1936), The Fascist Government of Italy, New York, van Nostrand.

SCHNEIDER Herbert W., (1938), "Review of Baumgarten (1938)," The Journal of Philosophy, 35, 695-8. SCHNEIDER Herbert W., (1947/1957), A History of American Philosophy [Deutsch: Geschichte der amerikanischen Philosophie (Übersetzung: Peter Krausser)], New York/Hamburg, Columbia University Press/Felix Meiner. 
SUKALE Michael, (1971), (Auswahl und Einleitung) Eduard Baumgarten: Gewissen und Macht. Abhandlungen und Vorlesungen 1933-1963, Meisenheim am Glan, Hain Verlag.

TILITZKI Christian, (2002), Die deutsche Universitätsphilosophie in der Weimarer Republik und im Dritten Reich (2 Teile), Berlin, Akademie Verlag.

VOGT Peter, (2002), Pragmatismus und Faschismus. Kreativität und Kontingenz in der Moderne,

Weilerswist, Velbrück Wissenschaft.

\section{NOTES}

1. James 1907.

2. James 1908.

3. Schlick 1910.

4. Jerusalem 1925.

5. Surprisingly in Habermas's "Erkenntnis und Interesse" 40 years later such a peculiar threepart division of the sciences pops up again, now only with the difference that religious knowledge is replaced by psychoanalysis and criticism of ideology: Habermas 1968; see for comments Dahms (1994: $369 \mathrm{ff}$.).

6. Baumgarten 1936.

7. Baumgarten 1938.

8. Burkamp 1938.

9. Gehlen 1940/1993.

10. Kempski 1952.

11. Baeumler 1931.

12. See Baumgarten's “vita," 7th of February 1933, in: Phil. Pers. Baumgarten (in UAG)

13. Its title was "Staatswissenschaftliche Austauschstelle beim Institut für Sozial- und Staatswissenschaften der Universität Heidelberg."

14. Hausmann 2003.

15. Dewey 1925.

16. Cited after a report of Baumgarten to Hecht, 20th January 1933, in: Phil. Pers. Baumgarten.

17. Ratzke 1987/1998.

18. There Brock wrote a book about the current philosophical situation in Germany; after 1945 he went back, but fell severely ill and so could not serve as Heideggers successor in Freiburg.

19. Husserl to Regierungspräsident, without date, in: Nohl papers in UBG, file 14: Dr. Baumgarten.

20. Rickert (without adressee), 2nd February 1933, in: Phil. Pers. Baumgarten (p. 354 f.)

21. Hausmann 2003.

22. Ebel (1962, 120, Nr. 11).

23. The circle was not an invention of the young Nazi regime, as Hausmann (2003: 216) writes.

24. Hecht to Neumann (dean of the Phil. Faculty of the Uni. of Göttingen, 30th January 1933, in: Pers. Phil. Baumgarten.

25. Protokollbuch der Phil. Fak., 17th February 1933, p. 83 f.

26. See Hausmann (2003: 218, fn 18) for a full list of all of Baumgarten's announcements during his time in Göttingen.

27. Opinion of Hans Lipps, 14th of June 1935, in: Phil. Pers. Baumgarten in UAG, see also Lipps's opinion on Baumgarten's pragmatism book, 29th of January 1936, ibidem.

28. Hausmann (2003: 222).

29. Baumgarten 1936. 
30. Copy cited from Heidegger (1933b/2000: 774), my translation; passages in italics are also found in the incomplete copy in the Baumgarten files in the UAG. The last sentence features only in the Göttingen copy. It is absent from Heidegger (1933b/2000: 775), where the editor states: "(a copy of the last sentence is missing)". See for other versions of Heideggers opinion Jaspers (1978: 14 f.), Farias (1989: 283 f.), and Ott (1988: 183).

31. Drexler told me this in an interview.

32. Cassirer (1981: 182).

33. See Heidegger 2014.

34. See Heidegger 1933a and Heidegger 2000 passim.

35. Dozentenschaft (Blume) to dean of the phil. faculty (Wilde), 15th of January 1935, in: Phil. Pers. Baumgarten (p. 327 f.).

36. This documentation survived in the Göttingen university archive as part of the new signature "Phil. Pers. Baumgarten" (formerly: "Habilitation Dr. Baumgarten").

37. Ebel (1962: 118, Nr. Ph. 1, 258).

38. (Ibid.: 117, Nr Ph 1, 245); for a description and discussion of the move from Hecht to Wilde see Scholl 1998.

39. Blume (Dozentenschaft) to Wilde (dean phil. fac.) 22nd of January 1936; my italics, in: Phil. Pers. Baumgarten.

40. That camp took place from the15th of Feb. to the 7th of March 1937. Baumgarten asked the dean on the 15th of March 1937 to send the certificate of participation to the ministry in Berlin.

41. I thank Brigitte Parakenings (Archive of Scientific Philosophy, Konstanz university) for the information that Baeumler's widow Marianne submitted to the archive only correspondence with Baumgarten dating from after 1945.

42. Baumgarten to Gaudozentenbundsführer Schürmann, 28th of December 1938, in: Phil. Pers. Baumgarten. That letter was written in the course of tumultuous events in the Göttingen philosophical faculty, where the doctoral thesis written by an American student of Baumgarten was judged negatively by the philosophy chairholder Hans Heyse, whereas Baumgarten critized heavily a dissertation thesis submitted under the supervision of Heyse. The confrontation even led to a call to a duel between Baumgarten and Schürmann, which did not take place only because of the outbreak of the Second World War. See more information on this strange episode Dahms (1987/1998: 306 f.). Baumgarten declined the call to Berlin in 1936 (mentioned above), because he wanted to pursue a career as a philosopher and not as a political scientist (and have a smaller teaching load than the 10 weekly hours in Berlin).

43. Baeumler 1926/1934.

44. See for example Nietzsche (1930); Baeumler regarded "The Will to Power" as Nietzsche's main work.

45. Baeumler 1931.

46. See especially the chapter II, 3: „Rousseau. Gegen Demokratismus und Sozialismus,” (ibid., 113-9).

47. (Ibid.: 183); Baumgarten did not need to change that paragraph in the reprints of the booklet in Nazi times.

48. Leaman (1993: 100).

49. Tilitzki; this speech is not mentioned in Baeumlers defense in the denazification process: see

M. Bauemler, Bruntäger \& Kurzke (1989: 192 ff.).

50. See Tilitzki (2002, passim).

51. It is interesting to note that Heidegger later on made at least an effort to deal with pragmatism. In his Schwarze Hefte of 1939 he has an entrance "Pragmatismus," where he characterizes this philosophy as consequence of an utmost rationalism: Heidegger (2014: 39).

52. It was not only popular among right-wing academics, but also was shared by some on the left (like Theodor Adorno, Ernst Bloch, Max Horkheimer and Herbert Marcuse, who came to the USA 
as emigrants from Hitler Germany). See Dahms 2018 for a description and assessment of the Frankfort schools view of pragmatism.

53. Baumgarten (1938: 60).

54. Baumgarten (1956: 94).

55. Baumgarten (1956: 94).

56. Baumgarten 1939 .

57. Baumgarten 1956

58. Compare its announcement as a chapter in the content list (ibid.: 93) and on page 152, where it was not delivered in the text, but only announced for another article (which to my knowledge was not published).

59. Habermas 1968, Apel 1973.

60. Peirce (1978/1934: 258, §402).

61. (Ibid.: 255)

62. The single exception was Jürgen von Kempski, who wrote a short review in the Deutsches Adelsblatt in 1938.

63. Baumgarten (1938: XI).

64. (Ibid.: 456).

65. Vogt (2002: 17).

66. (Ibid.), see also $190 \mathrm{ff}$.

67. Baumgarten 1934b.

68. (Ibid.).

69. Leaman (1993: 100).

70. Baumgarten (1938: 95).

71. (Ibid.: 96).

72. Hausmann (2003: 223).

73. (Ibid.).

74. Schelsky 1940; see for Schelsky's habilitation Tilitzki (2002: 727 ff.).

75. (Ibid.).

76. Schneider 1938.

77. Schneider 1947/1957.

78. Schneider 1928.

79. Schneider 1936.

80. Vogt (2002: 41-60).

81. Vogt (2002: $52 \mathrm{ff}$.$) .$

82. Schilpp to Baumgarten, 13th of Dec. 1938, in: Phil. Pers. Baumgarten in UAG.

83. Schilpp 1938; see for he causes of the rejection Dahms (1987/1998: 302).

84. (Ibid.: $1 \mathrm{f}$.); It seems to me that - mutatis mutandis - similar worries could be named with today's course of world events.

85. (Ibid.: 78).

86. (Ibid.: 79).

87. (Ibid.: 79).

88. (Ibid.: 81); Schilpp seems to have followed very closely the religious battle (Kirchenkampf) between the state-official "Deutsche Christen" on the one hand and the opposing "Bekennende Kirche" (Confessing Church) on the other.

89. See Leaman (1993: 244-7) for lists of organizers and participants as well as the programme of that conference and Tilitzki (2002: 955-63) for additional information on the talks, discussion participants and their theses and viewpoints

90. (Tilitzki 2002: 958).

91. Gehlen 1940/1993; see also Joas (1992 b: 130) and Karl-Siegbert Rehberg's introduction to Gehlen 1940/1993. 
92. See for details Tilitzki (2002: 789 ff.).

93. Baumgarten 1945.

94. Baumgarten 1964.

95. See Albert 1971.

96. Joas (1992 b: 133).

97. See for other rather difficult examples in philosophy in Göttingen alone Dahms (1987/1998).

98. See more titles in Hausmann (2003: 225, footnote 37).

\section{ABSTRACTS}

In this article I try to answer one central question: how can it be explained that the most intense reception of American pragmatism in Germany took place during the Nazi dictatorship (and not in democratic political environments before - during the Weimar Republic - and afterwards - in the first 20 years of the Federal Republic)? The answer is complicated: it starts with an academic exchange programme between Germany and the USA which brought the young post-doc Eduard Baumgarten in the mid -20ties to America and put him in contact with John Dewey and some of his pupils. After his return in 1929 he hoped to write and teach about pragmatism. This project came to an abrupt end, when Martin Heidegger denied him a promised position at the university of Freiburg. After the Nazi "seizure of power" the situation became worse when a completely negative expert opinion by Heidegger, by then the leading Nazi philosopher, blocked Baumgartens habilitation in Göttingen. Baumgarten fought back and established ties to a rising star in Nazi-philosophy, Alfred Baeumler, a devoted follower of Nietzsche's "Will to Power." This move secured in the end the publication of Baumgarten's two books on American philosophy and especially on pragmatism. But this triumph came at a cost: a "reinterpretation" of the democratic content of pragmatism and an effort to show similarities between it and Nietzsche's philosophy.

\section{AUTHOR}

\section{HANS-JOACHIM DAHMS}

Institut Wiener Kreis, Universität Wien

hans-joachim.dahms[at]univie.ac.at 